\title{
Liberalizing Immigration Policies for the UK Agricultural Sector in the Post-Brexit Era
}

\author{
Simone Angioloni ${ }^{1}$, Maria Berrittella ${ }^{2+}$, Ziping $\mathrm{Wu}^{1}$, and Angel H. Aguiar ${ }^{3}$ \\ ${ }^{1}$ Agri-Food Biosciences Institute, UK \\ ${ }^{2}$ Università degli Studi di Palermo, Italy \\ ${ }^{3}$ Purdue University, USA
}

\begin{abstract}
We investigate the effects of immigration policies on the UK agricultural sector under the new post-Brexit deal through a computable general equilibrium framework. We consider bilateral flows of migrants and frictions as part of capital and labor mobility to compare the point-based immigration system to open immigration policies in terms of their impacts on agriculture. We also integrate the GTAP-GMig2 immigration model with the GTAP-AGR agriculture model. Our findings show that liberal immigration policies have positive effects on production, farmers' income, and overall welfare. The benefits increase if these policies are combined with reduced bureaucracy and lower behind-the-border costs in trade relationships.
\end{abstract}

Keywords: agriculture; Brexit; computable general equilibrium; immigration; labor market

JEL Classifications: C68; E24; F16; J61; Q11

Received 30 July 2021, Revised 29 Setember 2021, Accepted 18 October 2021

\section{Introduction}

After more than four years of negotiations and political debate, the UK and EU signed a trade and cooperation agreement on December 24, 2020, which paved the way for the UK to have a smooth Brexit on January 1, 2021 (UK Government, 2021a). Under the agreement, the two partners agreed to a post-Brexit trade deal (PBTD) to regulate their trade relationship based on the mutual recognition of zero tariffs and zero quotas on the flow of goods. In addition,

\footnotetext{
+Corresponding Author: Maria Berrittella

Dipartimento di Scienze Economiche Aziendali e Statistiche, Università degli Studi di Palermo, Viale delle Scienze, 90128, Palermo, Italy. Email: maria.berrittella@unipa.it

Co-Author: Simone Angioloni

Economics Research Branch, Agri-Food Biosciences Institute, 18a Newforge Lane, BT9 5PX, Belfast, UK.

Email: simone.angioloni@afbini.gov.uk

Co-Author: Ziping Wu

Economics Research Branch, Agri-Food Biosciences Institute, 18a Newforge Lane, BT9 5PX, Belfast, UK.

Email: ziping.wu@afbini.gov.uk

Co-Author: Angel H. Aguiar

Global Trade Analysis Project, Purdue University, 403 West State Street, West Lafayette, Indiana, 479072056 , USA.

Email: aaguiar@purdue.edu
} 
the deal allows the UK to move away from EU rules on conformity, safety, and sanitary standards (e.g., SPS) for trade products and introduces a governance structure for resolving disputes. Failure to conform to EU standards would create additional customs hurdles for certain UK products. The PBTD sets forth the basis for the UK-EU relationship, which will take years to become fully defined.

As part of its post-Brexit strategy, the UK introduced a points-based immigration system (PBIS) that treats EU and non-EU citizens equally. In essence, the new system is designed to control and limit the inflow of unskilled EU migrants in the post-Brexit era. Under the PBIS, anyone coming to the UK for work must meet certain requirements, such as the ability to speak English at a certain level, having a job offer from a licensed sponsor, and being a skilled worker (i.e., making a salary above $£ 26,500$ per year; UK Government, 2021b). Work visas are awarded to those above the point threshold. The UK uses several ad hoc immigration schemes to integrate the points-based immigration system. Shortage Occupation Lists amend the PBIS by granting a Tier 2 visa to migrants with a job offer from a UK employer in specific sectors of the economy. For example, in 2020, the UK extended the quotas of Tier 2 visas for semi-skilled workers, such as nurses and paramedics, because of the COVID-19 pandemic. Tier 2 visas are temporary, lasting only the duration of the job offer, and, most importantly, they do not allow migrants to change employment sector. The seasonal agricultural workers scheme (SAWS) and sector-based schemes were designed to maintain a steady unskilled labor supply in specific agriculture industries, such as horticulture, meat slaughtering, and seasonal agricultural work. In the UK, these immigration schemes were operative until 2013, when the high inflow of unskilled labor from Eastern Europe made them obsolete. Concerned that the PBIS would reduce the supply of unskilled agricultural labor in the post-Brexit era, the UK government introduced a SAWS pilot for 2,500 workers in 2019. The UK later extended the pilot scheme to 30,000 workers, although many employers in agriculture consider this level insufficient, as they cannot attract domestic workers at current wages (UK Government, 2021c).

Although a substantial body of research has examined how Brexit has affected the UK economy, especially its agricultural sectors (Bellora et al., 2017; Boulanger \& Philippidis, 2015; Latorre et al., 2020; Philippidis, 2019),1) these studies focus on trade negotiations, analyzing immigration as an alternative scenario not directly framed in their models. In addition, these studies assess the ex-ante impact of restrictive immigration policies due to Brexit, neglecting to evaluate the effect of sectorial liberalized immigration policies (LIP), which are critical in

1) Latorre et. al. (2020) provided a comprehensive review of 15 empirical studies on Brexit. Philippidis (2019) integrated the MAGNET model of the EU Commission with FAPRI, a partial equilibrium model used by the four UK administrations for agricultural policy, to assess the impact of various Brexit deals on UK agriculture. Bellora, Emlinger, and Foure (2017) used a recursive dynamic general equilibrium model (MIRAGE) to assess the impact of various WTO-type deals on UK and EU agriculture. Finally, Boulanger and Philippidis (2015) was the first study on Brexit to apply a computable equilibrium model (MAGNET) before the referendum vote. 
the post-Brexit era. The post-Brexit era represents an interesting case study by which to examine the economic compromises between trade and immigration policy that a country faces when it engages/disengages itself from a free trade association (Hallett, 2019; Roy \& Mathur, 2016; Thangavelu, 2017).2) Such a study is useful for all countries interested in assessing their trade and immigration options for a specific sector or for the economy as a whole. This study contributes to the literature by examining the effectiveness of liberalized immigration policies in the agriculture sector, as well as its potential shrinkage due to Brexit.

We investigate the combined effects of the PBTD on the UK economy in terms of migration and trade using a comparative static, multi-commodity, and multi-regional computable general equilibrium (CGE) model of global trade and immigration. Specifically, we consider the impact of post-Brexit policies, introducing a series of specificities for the agricultural sector and the labor market in the CGE model. We do this by comparing the immigration policy being planned by the UK government for the post-Brexit era (a point-based scheme with zero unskilled migrants) to a similar policy that mitigates the reduction of unskilled migrant labor only in the agriculture and food processing sectors. This policy can be implemented via Shortage Occupation Lists, seasonal worker schemes, and sector-based schemes that prevent migrants from changing their employment sector. The LIP employed in this study was designed to cover the PBIS-related reduction of the unskilled labor force in the agri-food sector. The size of the labor shock is around 26,000 full-time equivalent laborers, which is similar to the scale addressed by previous UK sectorial policies implemented in agri-food before the inflow of EU workers began.

The study's results indicate that LIP has positive effects on production $(0.03 \%)$ and farmers' incomes $(0.04 \%)$. Market prices do not change $(0.00 \%)$, while unskilled wages in agriculture decrease by $0.17 \%$. Overall, for the entire economy, welfare gains range from USD 641 million to USD 668 million. The results are consistent in both sign and magnitude under the current Brexit deal and future potential post-Brexit scenarios, reflecting possible improvements or deterioration in EU-UK trade conditions.

The rest of the paper is organized as follows. The next section provides background for the study. Section III describes the study's model and data calibration. Section IV explains the design of the policy experiments. Section V discusses the study's results. Finally, Section VI presents conclusions and policy implications.

2) Hallett (2019) provided an extensive literature review and estimates on the exit costs of leaving a trade association with a special focus on the UK. Thangavelu (2017) analyzed the effect of skilled and unskilled foreign labor on a small open economy such as Singapore with a general equilibrium approach. Similarly, Roy and Mathur (2016) employed a general equilibrium approach to study how a bilateral trade agreement between the EU and India would affect the UK, India's main trading partner in Europe. 


\section{Background}

Immigration increased in the UK after WWII, but immigrant inflow to the UK has grown substantially over the last 20 years (Manacorda, Manning, and Wadsworth, 2012). Before the EU's 2004 enlargement, most migrant workers in the UK came from EU14 countries. However, the EU's free movement of people and favorable wage differentials stimulated a substantial inflow of labor from new member states, which constituted the majority group soon after the EU enlargement (Angioloni and $\mathrm{Wu}, 2020$ ).

Immigration can affect labor supply and demand in the host country. On the supply side, immigration promotes labor specialization, which requires occupations and industries in which native and migrant workers have a comparative advantage (Peri \& Sparber, 2009; Peri \& Sparber, 2011). On the demand side, businesses tend to choose a specific type of capital equipment, such as more manual-intensive technology, in response to the inflow of unskilled migrant labor (Acemoglu, 2002; Lewis, 2011; Peri, 2012 ). These factors are important for the agricultural sector, as seen in the inflow of Mexican pickers to California (Richards, 2018) and in the migrant inflow to the UK after the EU's 2004 enlargement. Figure 1 shows the distribution of unskilled migrant labor by industry in the UK. It indicates that the agri-food sector features a substantial proportion of unskilled occupations covered by migrant workers. In addition, Figure 2 shows that $77 \%$ of unskilled migrant workers employed in the agri-food sector come from the European Economic Area (EEA), making agri-food the industry with the highest concentration of unskilled EEA labor in the UK.

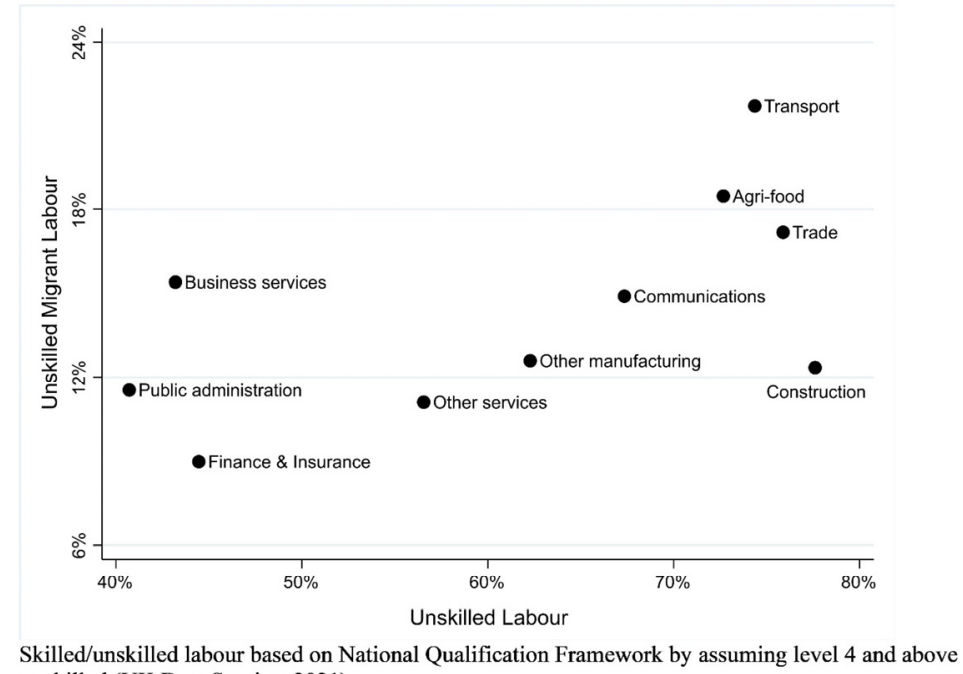
as skilled (UK Data Service, 2021).

Figure 1. Distribution of unskilled and migrant labour in UK by industry 


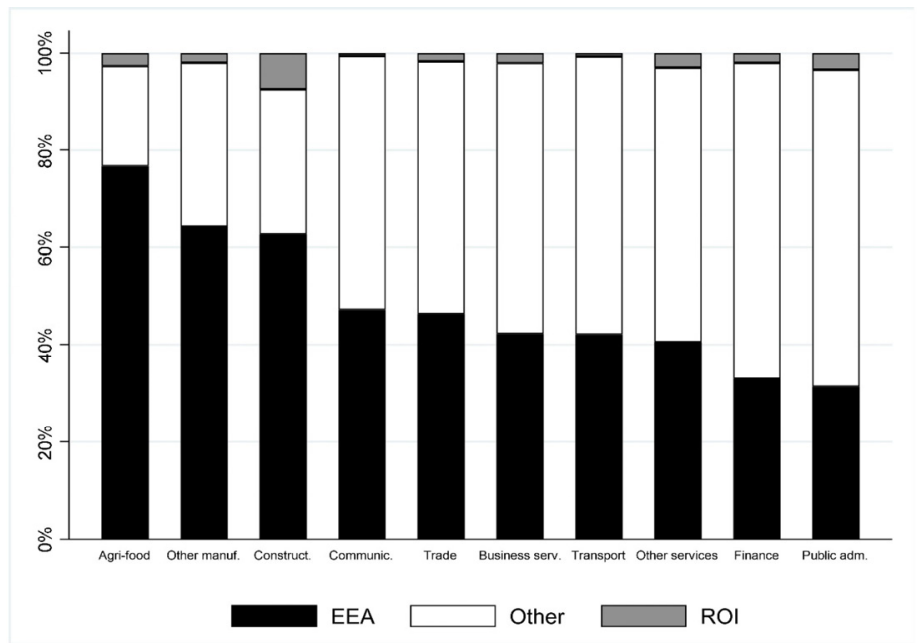

EEA (European Economic Area), ROI (Republic of Ireland), Other (Rest of the World). Table 1 of the appendix shows the countries included in each regional bloc. Source: UK Data Service (2021).

Figure 2. Distribution of unskilled migrant labour by industry and origin in UK

Several quantitative studies have employed CGE modelling to analyze ex-ante trade, immigration, agriculture, and Brexit. The UK government assessed various trade and immigration scenarios for four macro sectors of its economy - agriculture, food processing, manufacturing, and servicesbased on a CGE model; it found that a zero level of skilled and unskilled immigration from EU countries would reduce the UK's GDP by between $0.1 \%$ and $1.8 \%$, depending on the trade agreement, over a 10-year prediction window (UK Government, 2018). Other CGE models have combined technology and firm heterogeneity with variety effects to study the impact of border barriers and trade diversion due to Brexit. For example, Latorre et al. (2020) provided a comprehensive review of quantitative Brexit studies, finding that their broad consensus is that the greatest welfare losses for the UK will come from behind-the-border costs, immigration, and barriers to foreign direct investment.

Agriculture is the sector most heavily affected by trade and non-trade barriers. Numerous studies have examined the impact of Brexit on this industry using a CGE framework. Boulanger and Philippidis (2015) and Philippidis (2019) employed the MAGNET-CGE model of the EU Commission to assess the effect of various Brexit-related trade and macroeconomic scenarios. The overall impact of Brexit was found to be negative. Interestingly, however, the authors also found that gains in the agri-food sector from the UK CAP budget withdrawal would exceed the losses arising from the trade facilitation costs for single market access.

Several other CGE models investigate the impact of Brexit on agriculture using a different framework. For example, Bellora, Emlinger, and Foure (2017) employed the MIRAGE-CGE model, a recursive-dynamic computable general equilibrium model, to study the impact of various Brexitrelated trade and non-trade barriers on the agri-food sector. They found that, despite a decrease 
in exports to the UK due to the reduction of trade, the domestic production of red meat, cattle, and wheat would replace UK imports.

Regarding immigration and CGE modelling, Walmsley, Ahmed, and Parsons (2005) developed the GMig2 model, which tracks the bilateral movement of workers across countries and considers return migrants, remittances, and wage differentials. This model has been extensively employed to assess the economic effects of potential changes to immigration policy. For example, Aguiar (2009) extended the GMig2 model to include undocumented unskilled migrants in order to study the effects of both restrictive and liberalizing US immigration policy scenarios. Concerning the Brexit debate, Hosoe (2018) employed the GMig2 model with constant and increasing returns to scale to assess the effects of border barriers and migrant return and found that the UK's IT sector would be the industry most heavily affected by a reduction in skilled EU labor and that the agriculture sector would be heavily affected by a reduction in unskilled EU labor.

Therefore, understanding how trade and immigration policies affect UK agriculture has been the focus of research within and outside the Brexit debate, as it is important for the industry. However, few studies have examined the trade-offs between trade and immigration policy in the post-Brexit era. This study integrates two GTAP models, the GTAP-AGR model and GMig2 model, to assess the ex-ante impact of liberalized immigration policy on the UK agricultural sector in the post-Brexit era. The next section describes the study's model and data calibration method.

\section{Model and Data Calibration}

To assess the systemic, general equilibrium effects of trade and immigration policy, we apply the GMig2 model developed by Walmsley, Ahmed, and Parsons (2005), which tracks the bilateral movement of workers across countries. GMig2 is a modified version of the standard GTAP model (Hertel, 1997), a multiregional, comparative-static, CGE model designed to analyze he effects of trade policies.

The GMig2 model allows the study of immigration changes by skill type and country of origin, but not by industry, making it difficult to fully assess the effect of sectorial migration policies. Consequently, we modified the GMig2 model to include the labor force and migration flow distribution across skill types among sectors and countries, as in Aguiar (2009).

In addition, the standard GTAP model does not include some of the features of the agricultural economy that are required to assess the linkages between tariff and non-tariff shocks and the responses of farmers and food processors. Consequently, we introduced agricultural specificity into the GMig2 model to capture those features. The next sections provide an overview of the standard model and our modifications; the main literature can be referred to for further details (Aguiar, Narayanan, \& McDougal, 2016; Walmsley, Ahmed, \& Parsons, 2005; Kenney \& Hertel, 
2005; Hertel, 1997).

\section{A. Standard GTAP model}

On the consumption side, the economy is modelled by a representative household in each region whose Cobb-Douglas utility function allocates expenditures between private consumption, government consumption, and savings expenditure (Hertel, 1997). The constrained optimizing behavior for the private consumption of the household in a region is represented by a non-homothetic constant difference of elasticity (CDE) expenditure function for the set of goods and services. A Cobb-Douglas sub-utility function is employed for government spending. Private and government consumption are split into a series of alternative composite Armington aggregates. Savings are exhausted on investment, and capital markets are assumed to be in equilibrium only at the global level.

The technology is simplified by employing a constant elasticity of substitution (CES) functional form. Both intermediate and final products from different regions are considered to be imperfectly substitutable. All factor inputs (land, labor, capital, and natural resources) are immobile across regions and are typically assumed to be fully employed. Within a region, capital and labor are perfectly mobile across sectors.

Every economy includes government interventions with tax payments, and all taxes levied in the economy always accrue to the regional household. Flow-on effects to other countries are also captured in the model via bilateral trade relations from/to all countries and regions in the world.

\section{B. Labor immigration}

The GMig2 model tracks the movement of migrant workers across regions with free labor movement. Specifically, labor-exporting (home) countries see their labor force reduced when workers migrate to another country/region (Walmsley, Ahmed, \& Parsons, 2005; Walmsley et al., 2013). Similarly, the labor force increases in the labor-importing (host) country with the inflow of foreign workers. Changes to the labor force in home and host countries are then allocated across sectors to equalize the percentage change in wages for domestic and foreign workers.

Four types of native-migrant workers are considered according to their income status: permanent residents, existing migrants, new migrants, and return migrants. It is assumed that the resident population owns every type of endowment, such as land, natural resources, capital, and labor, while migrants own only labor; income changes for every type of worker are determined accordingly (Walmsley, Ahmed, \& Parsons, 2005). Specifically, remittances reduce the income of migrants in the host country and increase the income of permanent residents in the home country. The income of new migrants and return migrants requires the conversion of earnings in the host 
country to those in the home country via purchasing power parity (PPP; Timmer \& Mensbrugghe, 2006). Finally, the flows of remittances from the host country back to the home country are assumed to be a constant proportion of income and to affect a country's balance of payments as part of the current transfers.

For every region and skill type, the standard GMig2 model allocates labor force shocks proportionally across sectors. This assumption is appropriate for assessing an immigration shock that affects all sectors when the labor force of the baseline status reflects the current distribution; doing otherwise would generate distortive effects. However, this procedure is not suitable for analyzing policy shifts that affect only migrant workers from a specific region employed in a specific sector. Consequently, we modified the GMig2 model to include labor force and migration flow distribution across skill types, sectors, and regions, as in Aguiar (2009).

Two types of labor skills are considered: skilled and unskilled. To reflect domestic and foreign workers' different degrees of labor specialization, the model assumes that they are related by a finite elasticity of substitution - that is, that they are imperfect substitutes (Aguiar, 2009).

\section{Agriculture specificity}

One of the main criticisms of the standard GTAP model is that it does not capture the characteristics of agricultural markets that are important in assessing the impact of trade and immigration shocks. Following the GTAP-AGR model developed by Keeney and Hertel (2005), we introduced agricultural specificity in the production function to capture the fact that agricultural commodities are, first of all, inputs of other agricultural productions. The agricultural output is modelled using a CES production function combining two inputs, which are composite inputs. The first is a purchased input aggregate defined over intermediate agricultural goods. The second composite input is the value-added aggregate, as in the standard GTAP model. Individual inputs in each of these groups are assumed to be separable from one another and are modelled using a CES function.

The second important aspect of the farm and food marketing system relates to the croplivestock interactions generated by the use of feedstuffs in livestock production, which tend to exhibit changes in prices that are positively correlated. Following Rae and Hertel (2000), we capture the average degree of feedstuff substitution through a constant elasticity of substitution among crop and food products used in livestock production. The demand for feedstuffs is treated as a further CES nest below the purchased inputs aggregate.

The third modification regards the supply of primary factors. As in the GTAP-AGR, we introduce market segmentation for capital and labor in agriculture from the rest of the economy, leading to separate market-clearing conditions and thus different factor prices in the two markets (Keeney \& Hertel, 2005). There are two distinct markets for mobile factors, but labor and capital 
can move between them, though with some friction. The movement of factors between agricultural and non-agricultural markets is determined by changes in relative prices and the elasticity of transformation (i.e., the CET function).

Our fourth and final refinement is the introduction of farmers' incomes. Farmer income is defined as the value of the endowments owned by the agricultural sector, divided into on-farm and off-farm segments, minus the depreciation of capital in agriculture. The off-farm/on-farm disaggregation is calculated using the OECD shares of farmers' income in a region, and it is allocated proportionally across agricultural sectors. Similarly, the depreciation of capital is calculated in proportion to the depreciation of capital used in agriculture in a given region (Keeney \& Hertel, 2005).

\section{Data calibration}

The GMig2 model is calibrated using the GTAP database, version 9, which contains macroeconomic data for 2011. We use an aggregation of eight countries based on whether a country is a net labor exporter/importer. Table 1 of the appendix shows the regional aggregation.

The GMig2 database is a cross-sectional data of bilateral trade flows and national input-output tables. All the information in the database is reported in US dollar values.

Table 2 of the appendix shows the sectorial classification employed for agricultural and non-agricultural sectors, as defined in the GTAP-AGR model. For calibration purposes, we use the factor supply parameters to set the elasticity of supply for agriculture and the elasticities of substitution in agricultural production, as reported by Keeney et al. (2005).

Finally, the behavioral parameters utilized in the standard GTAP model are described in Aguiar, Narayanan, and McDougall (2016) as follows: (i) elasticities of substitution, in both consumption and production; (ii) transformation elasticities, which determine the degree of mobility of primary factors across sectors; (iii) the flexibility of regional investment allocation; and (iv) consumer demand elasticities. We employ the standard model's native-migrant elasticity of substitution differentiated by UK industry, as described by Angioloni and Wu (2020). The main advantage of this approach is that the demand for labor is articulated at the sectorial level, which helps us capture the effect of immigration restrictions not uniformly distributed across industries (Manacorda, Manning, \& Wadsworth, 2012). Tables A1, A2, and A3 show the elasticity estimated by industry. 


\section{Design of Simulation Exercises}

\section{A. Baseline}

The baseline scenario captures the "business as usual" status quo without any policy change. We incorporate the projections for the world and regional economies to the end of the prediction window, set as 2030 to allow the UK economy to completely absorb trade and immigration shocks. First, we employ the post-Brexit trade deal to represent the new trade relationship between the UK and the EU. The UK and EU agreed to not impose any trade tariffs or tariff rate quotas. However, as there is no agreement on the required technical, sanitary, and phytosanitary standards for products, Brexit implies more bureaucracy and delays for companies trading between the UK and EU, with a consequent increase in costs. Thus, we follow Philippidis (2019) and include an increase in trade costs, the so-called behind-the-border costs. For the PBTD baseline, we assume an increase in trade costs of $2 \%$ for crops, $5 \%$ for livestock, and $2 \%$ for the rest of the UK economy.

In the second major update to the baseline scenario, we incorporate the effects on real GDP and population growth of the COVID-19 pandemic. The UK and the rest of the world are heavily affected by the impact of the COVID-19 pandemic in terms of output and human lives. Consequently, in the baseline scenario, we update GDP and population growth in all the regions of the model. To do so, we employ the differences in the OECD's (2021) GDP predictions for the periods before and after the pandemic (December 2019). The OECD provides periodic real GDP predictions (at constant prices) based on macroeconomic models and expert judgments. Consequently, we consider the annual differences between the pre- and post-pandemic predictions for 2020, 2021, and 2022.

With regard to population, we aggregate the cumulative number of deaths by country (Our World in Data, 2021). This generates a daily time series for each region since the beginning of the pandemic. Then, we fit a Gompertz curve to each of the time series following the methodology described by Ohnishi et al. (2020) and calculate the upper asymptote - that is, the total number of deaths at the end of the process. In addition, we consider the effect of the vaccine by reducing these estimates by the predicted number of lives saved through the vaccine rollout to high-risk patients (Institute for Health Metrics and Evaluation, 2021). These estimates represent the effect of national campaigns aimed at vaccinating high-risk patients and (gradually) low-risk population cohorts implemented in the UK and other countries.

Finally, we update the UK labor force to the 2020 level, as reported by the Quarterly Labour Force Survey (UK Data Service, 2021). For every worker, we map by country of origin the four-digit standard industrial classification of UK industries into the GTAP sectors. We average over the four quarters of 2020 to remove seasonal effects that can substantially affect the estimates 
of the labor force in minor sectors. 3) Further, the baseline scenario assumes that the current immigration policy does not change, such that the modest reduction of the labor force $(-0.2 \%)$ would reflect the trend that started after the Brexit referendum, in which the number of EEA migrant workers in the UK has already dropped. This reduction in the labor force is estimated using the methodology described in the following section.

\section{B. Immigration scenarios}

We focus on EEA countries in our immigration scenarios, since the European Economic Agreement confers free movement onto EEA nationals, along with EU citizens (EEA, 2018).4) The calculation of immigration shocks is based on the estimates provided by the UK Government (2018) to assess the impact of the post-Brexit immigration system. These estimates aim to predict the net EEA immigration to the end of the prediction window (2030). This is performed in a series of steps. First, the relationship between the inflow of EEA workers and macroeconomic predictors such as the differentials of GDP, unemployment rate, and age profile between the UK and EEA countries are econometrically estimated. Second, the predictions of these macroeconomic variables are used to project the EEA migration inflow over time and calculate the cumulative inflow until 2030. Third, outflows of EEA workers are modelled in a simplified manner due to data limitations. Data on stay duration for long-term EEA migrants are employed to estimate the historical relationship between inflows and outflows. This relationship is then applied to the predicted cumulative inflow of EEA workers to estimate the corresponding outflow. The net flow is calculated as the difference between inflow and outflow; the results are employed to design two immigration scenarios.

The first immigration scenario, denoted "PBIS" (point-based immigration system), sets to zero only the net inflow of unskilled EEA workers. Overall, this immigration scenario implies a $1.1 \%$ decrease in the labor force. The second scenario, denoted "LIP," mitigates the reduction of unskilled migrant labor only in agriculture and food processing to reflect the potential shrinking of the sector because of PBIS. In all the immigration scenarios, it is assumed that shocks to the labor force are proportional across sectors, skill types, and EEA regions. The domestic labor force and immigration from the rest of the world are assumed to be constant through all estimates and simulations.

We assess the effectiveness of LIP in supporting the UK agricultural sector by comparing the changes in output, prices, farmers' incomes, welfare, and other factors due to PBIS. Specifically, we run the PBIS scenario and assess its impact on the UK economy. Then, we consider the

3) The skill distribution across regions and industries is based on the National Qualification Framework. We assume that workers at level 4 and above are skilled and the rest are unskilled (UK Data Service, 2021).

4) The EEA includes EU member states, European Free Trade Association States (EFTA), and Switzerland. The EFTA includes Iceland, Liechtenstein, and Norway (EEA, 2018). 
results of this scenario as the new baseline status and run the LIP immigration scenario. A similar design was implemented by the UK Government (2018) in a Brexit assessment based on the trade model developed by Balistreri, Böhringer, and Rutherford (2018).

\section{Future Post-Brexit scenarios}

The previous analysis compares the effect of PBIS and LIP with respect to the baseline, where the post-Brexit deal is supposed to follow the business-as-usual scenario. The PBTD sets the basis for the future trade relationship between the UK and the EU, and the two sides can move closer or farther apart depending on their agreements. Consequently, we implement two additional post-Brexit scenarios. The first, named Post-Brexit ${ }^{+}$, represents a situation where the trade relationship between the UK and EU is closer, with less bureaucracy and lower behindthe-border costs. In this case, we assume an increase in trade costs of $1 \%$ for crops, $3 \%$ for livestock, and $1 \%$ for the rest of the UK economy. By contrast, the Post-Brexit scenario considers a situation wherein the trade relationship is more distant, with an increase in trade costs of 3\% for crops, $7 \%$ for livestock, and 3\% for the rest of the UK economy. As mentioned, we consider that the immigration policy is implemented in addition to these shocks, allowing us to assess the effect of various immigration policies on UK agriculture over a wide spectrum of post-Brexit scenarios.

\section{Results and Discussion}

This section discusses the LIP policy test for the UK agricultural sector and the entire economy. The policy test is conducted by comparing the effects produced by LIP to those generated by the current points-based immigration system. Under this system, the reduction of only unskilled migrant labor force reduces agricultural production by $-0.41 \%$ and domestic sales by $-0.49 \%$. Wages decrease apart from unskilled labor, where the reduction in migrant labor increases its cost by $2.37 \%$. The reduction in agricultural production also determines the changes in price $(+0.02 \%)$ and quantity $(-0.43 \%)$ for feedstuff.

We find that PBIS negatively affects farmers' incomes by $-0.49 \%$. This change is determined by the off-farm component $(-0.56 \%)$, while the on-farm component shows a modest increase $(+0.09 \%)$. Table 1 shows that PBIS generates a welfare loss, mainly via a decrease in population $(-72 \%)$, although positive welfare changes are observed due to endowment effects, especially allocative efficiency (12\%). 
Table 1. Simulation Results Under Post-Brexit Trade Deal and Covid-19 Baseline Scenario

\begin{tabular}{|c|c|c|c|c|}
\hline Sector & Variable Type & Variable & $P B I S$ & $P B I S+L I P$ \\
\hline \multirow{14}{*}{ Agriculture } & \multirow{2}{*}{ Trade } & Imports & -0.40 & -0.38 \\
\hline & & Exports & -0.17 & -0.17 \\
\hline & \multirow{3}{*}{$\begin{array}{l}\text { Output } \\
\text { Market }\end{array}$} & Domestic sales & -0.49 & -0.46 \\
\hline & & Output & -0.41 & -0.38 \\
\hline & & Market price & 0.03 & 0.03 \\
\hline & \multirow{6}{*}{$\begin{array}{l}\text { Factor } \\
\text { Market }\end{array}$} & Agricultural Unskilled Labour & -1.07 & -1.00 \\
\hline & & Agricultural Unskilled Wage & 2.37 & 2.22 \\
\hline & & Agricultural Skilled Labour & -0.25 & -0.23 \\
\hline & & Agricultural Skilled Wage & -0.80 & -0.75 \\
\hline & & Feedstuff & -0.43 & -0.40 \\
\hline & & Feedstuff Price & 0.02 & 0.02 \\
\hline & \multirow{3}{*}{$\begin{array}{l}\text { Farmer's } \\
\text { Income }\end{array}$} & Overall Income & -0.49 & -0.45 \\
\hline & & On-Farm Income & 0.09 & 0.08 \\
\hline & & Off-Farm Income & -0.56 & -0.52 \\
\hline \multirow{7}{*}{$\begin{array}{c}\text { Whole } \\
\text { Economy }\end{array}$} & \multirow{7}{*}{$\begin{array}{c}\text { Welfare } \\
\text { Decomposition }\end{array}$} & Welfare Change ( $\$$ million) & $-8,751$ & $-8,109$ \\
\hline & & Terms of Trade & -206 & -178 \\
\hline & & Behind Border Costs & 0 & 0 \\
\hline & & Remittances & 882 & 874 \\
\hline & & Population & $-9,936$ & $-9,210$ \\
\hline & & Endowment & 593 & 515 \\
\hline & & Allocative Efficiency & 1,052 & 942 \\
\hline
\end{tabular}

The LIP, designed to cover the shortage of unskilled migrant labor in agriculture and food and drinks, can improve production and welfare. This is clear from the analysis of the output market, which shows that agricultural domestic sales improve from $-0.49 \%$ under the current immigration policy to $-0.46 \%$ under LIP. Similarly, the output market decreases by only $-0.38 \%$ under LIP (-0.41\% under PBIS alone). Regarding the factor market, LIP mitigates the labor force reduction induced by the post-Brexit immigration system and thus the wage change in agriculture. Under LIP, unskilled wages increase by $2.22 \%$ (2.37\% under PBIS alone), while skilled wages decrease by $-0.75 \%$ ( $-0.80 \%$ under PBIS alone). 5$)$ The more modest wage changes induced by LIP also have a positive effect on farmers' incomes, which decrease by $-0.45 \%$ ( $-0.49 \%$ under PBIS alone). Finally, the welfare loss due to population changes is lower under LIP (USD -9,210 million) than under PBIS alone (USD -9,936 million), indicating positive welfare gains for the whole UK economy of USD 641 million.

Table 2 shows the effect of immigration policies on alternative trade scenarios for the

5) In agriculture, the decrease in output due to the reduction in migrant labour reduces demand for the other primary factors, such as skilled labour, capital, and land, whose prices thus decrease. 
post-Brexit era. With regard to trade, a closer relationship with the EU increases farmers' incomes. Table 2 shows that the increase in farmers' incomes ranges between $0.47 \%$ and $0.51 \%$ under Post-Brexit ${ }^{+}$. By contrast, under Post-Brexit, the decrease in farmer's incomes ranges between $-1.54 \%$ and $-1.50 \%$.

Table 2. Simulation Results Under Different Post-Brexit Trade Scenarios

\begin{tabular}{|c|c|c|c|c|c|c|}
\hline \multicolumn{3}{|c|}{ Post-Brexit Scenario } & \multicolumn{2}{|c|}{ Post-Brexit $^{+}$} & \multicolumn{2}{|c|}{ Post-Brexit $^{-}$} \\
\hline Sector & Variable Type & Variable & PBIS & $P B I S+L I P$ & PBIS & $P B I S+L I P$ \\
\hline \multirow{14}{*}{ Agriculture } & \multirow{2}{*}{ Trade } & Imports & 0.96 & 0.99 & -1.78 & -1.75 \\
\hline & & Exports & 0.23 & 0.23 & -0.24 & -0.24 \\
\hline & \multirow{3}{*}{$\begin{array}{l}\text { Output } \\
\text { Market }\end{array}$} & Domestic sales & -1.55 & -1.52 & 0.60 & 0.63 \\
\hline & & Output & -0.95 & -0.92 & 0.29 & 0.31 \\
\hline & & Market price & 0.60 & 0.60 & -0.60 & -0.60 \\
\hline & \multirow{6}{*}{$\begin{array}{l}\text { Factor } \\
\text { Market }\end{array}$} & Agricultural Unskilled Labour & -1.97 & -1.90 & -0.09 & -0.02 \\
\hline & & Agricultural Unskilled Wage & 1.66 & 1.50 & 3.14 & 2.98 \\
\hline & & Agricultural Skilled Labour & -1.08 & -1.07 & 0.65 & 0.67 \\
\hline & & Agricultural Skilled Wage & -1.50 & -1.44 & -0.07 & -0.02 \\
\hline & & Feedstuff & -0.72 & -0.69 & -0.12 & -0.09 \\
\hline & & Feedstuff Price & 0.49 & 0.49 & -0.51 & -0.51 \\
\hline & \multirow{3}{*}{$\begin{array}{l}\text { Farmer's } \\
\text { Income }\end{array}$} & Overall Income & 0.47 & 0.51 & -1.54 & -1.50 \\
\hline & & On-Farm Income & -1.15 & -1.16 & 1.43 & 1.42 \\
\hline & & Off-Farm Income & 0.68 & 0.72 & -1.91 & -1.87 \\
\hline \multirow{8}{*}{$\begin{array}{l}\text { Whole } \\
\text { Economy }\end{array}$} & \multirow{8}{*}{$\begin{array}{c}\text { Welfare } \\
\text { Decomposition }\end{array}$} & Welfare Change ( $\$$ million) & 1,137 & 1,798 & $-19,644$ & $-18,976$ \\
\hline & & Terms of Trade & 5,244 & 5,277 & $-6,491$ & $-6,446$ \\
\hline & & Behind Border Costs & 4,020 & 4,020 & $-3,899$ & $-3,899$ \\
\hline & & Output & 602 & 594 & 1,189 & 1,181 \\
\hline & & Remittances & 526 & 452 & 496 & 428 \\
\hline & & Population & $-10,057$ & $-9,322$ & $-9,838$ & $-9,120$ \\
\hline & & Endowment & 1,901 & 1,785 & 406 & 286 \\
\hline & & Allocative Efficiency & 0.96 & 0.99 & -1.78 & -1.75 \\
\hline
\end{tabular}

Nevertheless, Table 2 shows that agricultural production in the UK decreases more under a closer trade relationship with the EU than in the baseline because less bureaucracy and lower trade costs allow the replacement of domestic production with imports from this region, as highlighted in previous studies (Bellora, Emlinger, \& Foure, 2017; Philippidis, 2019; Roy \& Mathur, 2016). For example, under Post-Brexit ${ }^{+}$, agricultural output decreases between $-0.95 \%$ and $-0.92 \%$. By contrast, under Post-Brexit, agricultural output increases between $0.29 \%$ and $0.31 \%$.

Changes in agricultural production also affect market prices and demand for primary factors. First, the agricultural market price increases by $0.60 \%$ under Post-Brexit ${ }^{+}$while it decreases by the same percentage under Post-Brexit . A similar change is observed in the price of feedstuff. 
Second, the decrease in agricultural output reduces the demand for labor and thus its price. Skilled wages decrease between $-1.44 \%$ and $-1.50 \%$ under Post-Brexit ${ }^{+}$, while they are basically unchanged under Post-Brexit. Similarly, the effect of reduced labor supply on unskilled agricultural wages is smaller under Post-Brexit ${ }^{+}$than under Post-Brexit .

Figure 3 shows the welfare decomposition of the two immigration policies under the alternative post-Brexit trade scenarios. The main driver of welfare loss due to PBIS is still population change (Aguiar, 2009). Nevertheless, different post-Brexit deals affect welfare changes via the terms of trade and behind-the-border costs in opposite directions. Under Post-Brexit ${ }^{+}$, these effects are positive and generate welfare gains ranging between USD 1,137 million and USD 1,798 million. By contrast, under Post-Brexit the effect moves in the same direction as PBIS, and the welfare loss is USD $-19,644$ million for PBIS and USD -18,976 million for LIP.

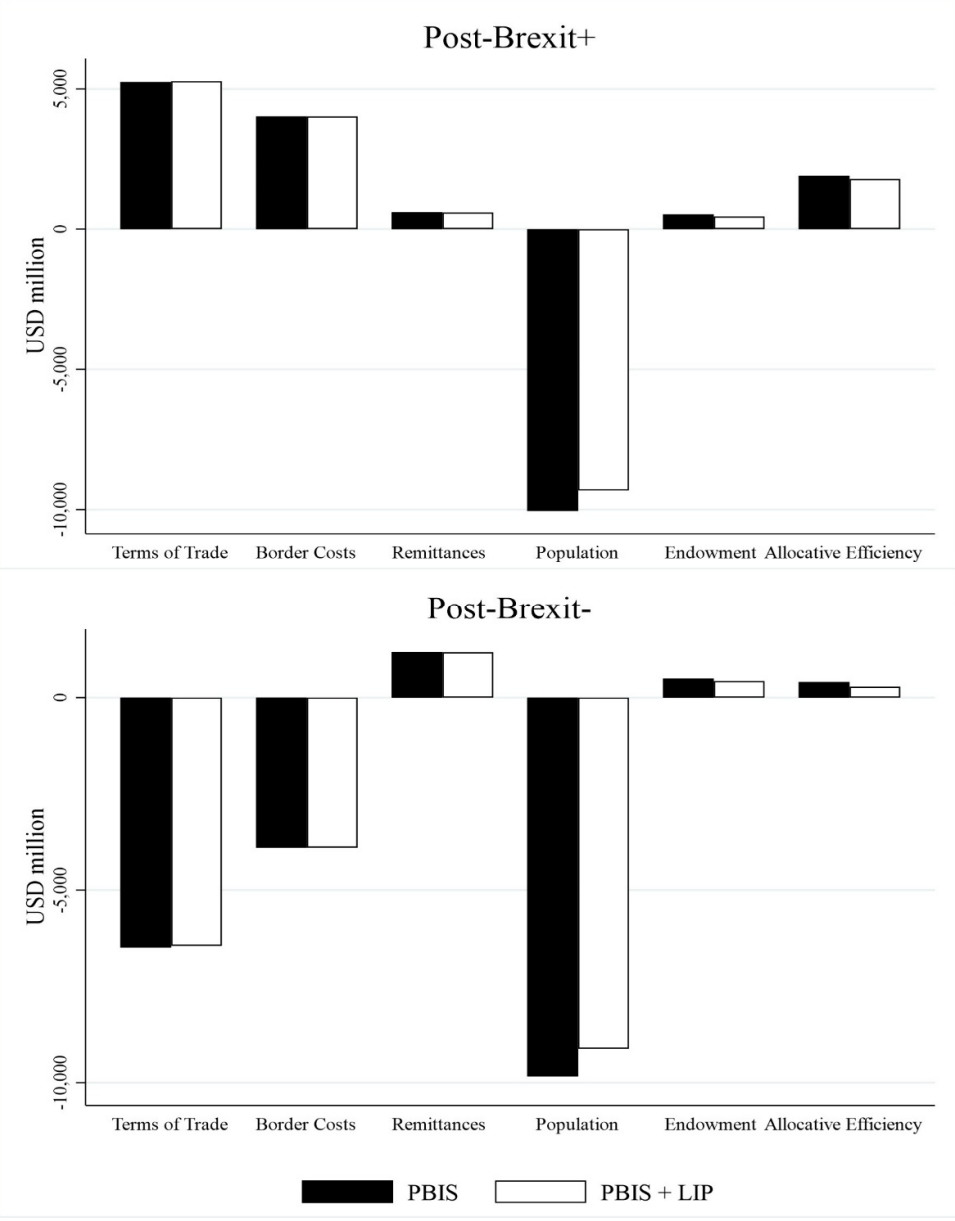

Figure 3. Welfare decomposition under different Post-Brexit trade scenarios 
Our analysis of different trade conditions confirms that LIP, intended to mitigate labor force reduction, improves production, farmers' incomes, and welfare. Table 1 shows that the welfare gains of LIP are equal to USD 642 million under the current post-Brexit deal. By contrast, Table 2 and Figure 3 show that the welfare gains of LIP total USD 661 million under Post-Brexit ${ }^{+}$ and USD 668 million under Post-Brexit .

\section{Conclusions}

We applied a multi-country CGE model to understand the effects of immigration policies on the UK agricultural sector in the post-Brexit era. We focused on policies intended to liberalize unskilled migrant labor, such as seasonal worker schemes, shortage occupational lists, and sector-based schemes. Under these policies, migrant workers can be employed only in the sector where they have received a job offer.

The findings indicate that LIP increases production in agriculture, sustains farmers' incomes, and mitigates wage growth due to PBIS. In addition, LIP generates welfare gains for the entire economy. Nevertheless, it is important to combine these policies with other ad hoc interventions. For example, promoting capital investment in agriculture can stimulate the demand for skilled labor and increase input diversification, and thus reduce the dependence on unskilled migrant workers in the sector (Richards, 2018). In addition, policymakers should try to transition the domestic labor force towards occupations currently covered by unskilled EEA migrants-for instance, through training courses and capital grants designed to promote employment on farms (Angioloni \& Wu, 2020). Finally, policies for mitigating the reduction of immigration in other sectors can sustain food demand and indirectly support agriculture.

The UK agri-food sector has enjoyed more than a decade of easy and cheap access to unskilled labor owing to the abundant availability of workers from Eastern Europe and favorable wage differentials. Nevertheless, this privileged access ended with the departure of the UK from the European Union and the introduction of the points-based immigration scheme. Moreover, the post-Brexit trade deal between the UK and the EU imposes no trade tariffs or tariff rate quotas, but it requires more bureaucracy and delays, especially for the agri-food sector. Concerns among farmers and food processors about trade costs, shortages of unskilled labor, and the difficulty of replacing it with native workers require that alternative immigration policies be considered.

The UK has the freedom to negotiate its EU trade conditions for every sector of its economy. There is no reason to assume that UK agriculture will end up having a trade relationship with the EU closer than that agreed upon in the PBTD. The outcome depends on the delicate balance of costs and benefits across sectors and the priorities of the UK government. This study indicates that LIP is an effective strategy for helping to sustain the sector amid shortages of unskilled 
migrant labor under a wide spectrum of UK-EU trade conditions.

\section{References}

Acemoglu, D. (2002). Directed technical change. The Review of Economic Studies, 69(4), 781-809.

Aguiar, A. H. (2009). An analysis of U.S. immigration and policy reforms (Doctoral dissertation). Purdue University, USA.

Aguiar, A. H., Narayanan, B., \& McDougall, R. (2016). An overview of the GTAP 9 data base. Journal of Global Economic Analysis, 1(1), 181-208.

Angioloni, S., \& Wu, Z. (2020). Native-migrant labour substitution by industry and wage effects: Evidence from the UK. Applied Economics, 52(42), 4639-4658.

Balistreri, E. J., Böhringer, C., \& Rutherford, T. (2018). Quantifying disruptive trade policies. CESinfo Working Paper, 7382. Retrieved from https://www.cesifo.org/DocDL/cesifo1_wp7382.pdf

Bellora, C., Emlinger, C., \& Foure, J. (2017). Research for AGRI Committee-EU-UK Agricultural trade: State of play and possible impacts of Brexit. Brussels: Policy Department for Structural and Cohesion, European Parliament. Retrieved from https:/www.europarl.europa.eu/RegData/etudes/STUD/2017/602 008/IPOL_STU\%282017\%29602008_EN.pdf

Boulanger, P., \& Philippidis, G. (2015). The end of a romance? A Note on the quantitative impacts of a "Brexit" from the EU. Journal of Agricultural Economics, 66, 832-842. https://doi.org/10.1111/147 $7-9552.12120$

EEA. (2018). European Economic Area (EEA). Relations with the EU (2018). Retrieved from https://www.e $\mathrm{fta}$.int/eea

Hertel, T. W. (1997). Global trade analysis modelling and application. Cambridge: Cambridge University Press.

Hallett, A. H. (2019). Throwing the baby out with the bathwater: Brexit and the economics of disengaging from a free trade association. Economic Analysis and Policy, 62, 91-96.

Hosoe, N. (2018). Impact of border barriers, returning migrants, and trade diversion in Brexit: Firm exit and loss of variety. Economic Modelling, 69, 193-204.

Institute for Health Metrics and Evaluation. (2021). Covid-19 projections-total deaths. Retrieved from www.healthdata.org

Keeney, R., \& Hertel, T. (2005). GTAP-AGR: A framework for assessing the implications of multilateral changes in agricultural policies. Resources Technical Paper, 24. Retrieved from https://www.gtap.agec on.purdue.edu/resources/download/2310.pdf

Latorre, M. C., Olekseyouk, Z., Yonezawa, H., \& Robinson, S. (2020). Making sense of Brexit losses: An in-depth review of macroeconomic studies. Economic Modelling, 89, 72-87.

Lewis, E. (2011). Immigration, skill mix, and capital skill complementarity. The Quarterly Journal of Economics, 126(2), 1029-1069.

Manacorda, M., Manning A., \& Wadsworth, J. (2012). The impact of immigration on the structure of 
wages: Theory and evidence from Britain. Journal of the European Economic Association, 10(1), 120-151.

OECD. (2021). Real GDP forecast (indicator). Retrieved from https://doi.org/10.1787/1f84150b-en

Ohnishi, A., Namekawa, Y., \& Fukui, T. (2020). Universality in COVID-19 spread in view of the Gompertz function. Progress of Theoretical and Experimental Physics, 2020(12), 1-20.

Our World in Data. (2021). Total confirmed COVID-19 deaths. Retrieved from https://ourworldindata.org/c ovid-deaths

Peri, G. (2012). The effect of immigration on productivity: Evidence from US states. The Review of Economics and Statistics, 94(1), 348-358.

Peri, G., \& Sparber, C. (2011). Assessing inherent model bias: An application to native displacement in response to immigration. Journal of Urban Economics, 69(1), 82-91.

Peri, G., \& Sparber, C. (2009). Task specialization, immigration, and wages. American Economic Journal: Applied Economics, 1(3), 135-169.

Philippidis, G. (2019). Brexit: How might UK agriculture thrive or survive? Computable general equilibrium. Newcastle: Newcastle University Final Report. Retrieved from https://research.ncl.ac.uk/esrcbrexitproje ct/outputs/

Rae, A. N., \& Hertel, T-W. (2000). Future developments in global livestock and grains markets: The impacts of livestock productivity convergence in Asia-Pacific. Australian Journal of Agricultural and Resource Economics, 44, 393-422.

Richards, T. J. (2018). Immigration reform and farm labor markets. American Journal of Agricultural Economics, 100, 1050-1071.

Roy, A., \& Mathur, S. K. (2016). Brexit and India-EU Free Trade Agreement. Journal of Economic Integration, 31(4), 740-773.

Thangavelu, S. M. (2017). Labour market immigration with the world: Case of Singapore. Journal of Economic Integration, 32(3), 723-758.

Timmer, H., \& Van der Mensbrugghe, D. (2006). International migration, purchasing power parity (PPP) and the money metric of welfare gains. Proceedings from World Bank $9^{\text {th }}$ Annual Conference on Global Economic Analysis. Washington DC. Retrieved from https://gtap.agecon.purdue.edu/resources/ download/2625.pdf

UK Data Service. (2021). Quarterly Labour Survey-Four Quarters. Nesstar Catalogue (2020). Retrieved from https://www.ukdataservice.ac.uk/get-data/explore-online/nesstar/nesstar.aspx

UK Government. (2021a). Trade and cooperation agreement-including annexes and protocols. Agreements Reached Between United Kingdom of Great Britain and Northern Ireland and the European Union. Retrieved from https://assets.publishing.service.gov.uk/government/uploads/system/uploads/attachment _data/file/948119/EU-UK_Trade_and_Cooperation_Agreement_24.12.2020.pdf

UK Government. (2021b). The UK's points-based immigration system: Information for EU citizens. Retriev ed from https://www.gov.uk/guidance/the-uks-points-based-immigration-system-information-for-eu-cit izens

UK Government. (2021c). Seasonal workers pilot request for information. Retrieved from https://www.gov. uk/government/publications/seasonal-workers-pilot-request-for-information/seasonal-workers-pilot-req 
uest-for-information

UK Government. (2018). EU exit: Long-term economic analysis (Technical Reference Paper). Exiting the European Union-Publications. Retrieved from https:/assets.publishing.service.gov.uk/government/ uploads/system/uploads/attachment_data/file/760484/28_November_EU_Exit_-_Long-term_economic _analysis____.pdf

Walmsley, T. L., Aguiar, A., Hussein, Z., \& Parsons, C. R. (2013). The GMig2 data base: Extending the GTAP 8 to include global bilateral migration, wages and remittances. GTAP Resources Technical Paper, 4044. Retrieved from https://www.gtap.agecon.purdue.edu/resources/download/6490.pdf

Walmsley, T. L., Ahmed, S. A., \& Parsons, C. (2005). A global bilateral migration data base: Skilled labor, wages and remittances. GTAP Research Memoranda, 1880. Retrieved from https://www.gtap.age con.purdue.edu/resources/res_display.asp?RecordID $=1880$ 
Table A1. Regional Aggregation and Labour Migration in the GMig2 Model

\begin{tabular}{lll}
\hline \multicolumn{1}{c}{ Region } & \multicolumn{1}{c}{ Countries } & Migratory Flow \\
\hline NAFTA & Mexico and rest of NAFTA & Labour exporting \\
EEA1 & $\begin{array}{l}\text { Austria, Belgium, Cyrus, Denmark, Finland, France, Germany, Greece, Italy, } \\
\text { Luxemburg, Malta, Netherlands, Portugal, Spain, and Sweden }\end{array}$ & Labour importing \\
EEA2 & Czech Republic, Estonia, Hungary, Latvia, Lithuania, Poland, Slovakia, & Labour exporting \\
& Slovenia, Bulgaria, Croatia, and Romania & \\
ROW & Rest of the world & Labour exporting \\
UK & United Kingdom & Labour importing \\
UC & USA and Canada & Labour importing \\
ROI & Republic of Ireland & Labour importing \\
EFTA & Iceland, Liechtenstein, Norway, and Switzerland & Labour importing \\
\hline
\end{tabular}

Table A2. Sectorial Aggregation Employed in the GTAP-AGR Model

\begin{tabular}{|c|c|c|c|}
\hline Label & GTAP Description & Trade Commodities & Feedstuff \\
\hline pdr & Paddy rice & Agriculture & Feed \\
\hline wht & Wheat & Agriculture & Feed \\
\hline gro & Cereal grains & Agriculture & Feed \\
\hline$v_{-} f$ & Vegetables, fruit, nuts & Agriculture & Feed \\
\hline osd & Oil seeds & Agriculture & Feed \\
\hline c_b & Sugar cane, sugar beet & Agriculture & Feed \\
\hline $\mathrm{pfb}$ & Plant-based fibres & Agriculture & Feed \\
\hline ocr & Crops & Agriculture & Non-feed \\
\hline ctl & Cattle, sheep, goats, horses & Agriculture & Livestock \\
\hline oap & Animal products & Agriculture & Livestock \\
\hline rmk & Raw milk & Agriculture & Livestock \\
\hline wol & Wool, silk-worm cocoons & Agriculture & Livestock \\
\hline frs & Forestry & Agriculture & Non-feed \\
\hline fsh & Fishing & Agriculture & Non-feed \\
\hline OthPrimary & Coal, oil, gas, other mining & Non-Agriculture & Non-feed \\
\hline $\mathrm{cmt}$ & Meat: cattle, sheep, goats, horse & Food processing & Feed \\
\hline omt & Meat products & Food processing & Feed \\
\hline vol & Vegetable oils and fats & Food processing & Feed \\
\hline mil & Dairy products & Food processing & Feed \\
\hline pcr & Processed rice & Food processing & Feed \\
\hline sgr & Sugar & Food processing & Feed \\
\hline ofd & Food products & Food processing & Feed \\
\hline b_t & Beverages and tobacco products & Food processing & Non-feed \\
\hline texwap & textiles, wearing apparel, leather & Non-Agriculture & Non-feed \\
\hline woodpap & lumber and paper products & Non-Agriculture & Non-feed \\
\hline pchemineral & petroleum, chemical, mineral & Non-Agriculture & Non-feed \\
\hline
\end{tabular}


Table A2. Continued

\begin{tabular}{llll}
\hline \multicolumn{1}{c}{ Label } & \multicolumn{1}{c}{ GTAP Description } & Trade Commodities & Feedstuff \\
\hline metals & ferrous, metals, and metal products & Non-Agriculture & Non-feed \\
autos & motor vehicles and parts & Non-Agriculture & Non-feed \\
othmnfcs & transport equipment, machinery, manufactures & Non-Agriculture & Non-feed \\
Electronics & electronics equipment & Non-Agriculture & Non-feed \\
hhutilities & electricity, gas, water utility & Non-Agriculture & Non-feed \\
Construction & construction & Non-Agriculture & Non-feed \\
Trade & trade & Non-Agriculture & Non-feed \\
Transport & water, air, and other transport & Non-Agriculture & Non-feed \\
Comm & communication & Non-Agriculture & Non-feed \\
FinanceInsur & finance and insurance services & Non-Agriculture & Non-feed \\
Busservices & business services & Non-Agriculture & Non-feed \\
Otherservice & recreational and other service & Non-Agriculture & Non-feed \\
PublidAdm & public administration, defence, health, education & Non-Agriculture & Non-feed \\
\hline
\end{tabular}

Table A3. Native Migrant Elasticity of Substitution by Industry in UK

\begin{tabular}{clcc}
\hline Label & \multicolumn{1}{c}{ GTAP Sector } & Industry & Elasticity \\
\hline pdr; wht; grow; & paddy rice; wheat; cereal grains; vegetables, fruit, nuts; oil & Agri-Food & 3.59 \\
v_f; osd; c_b; & seeds; sugar cane, sugar beet; plant-based fibres; crops; & \\
pfb; ocr; ctl; & cattle, sheep, goats, horses; animal products; raw milk; wool, & \\
oap; rmk; wol; & silk-worm cocoons; forestry; fishing; meat: cattle, sheep, & \\
frs; fsh; cmt; & goats, horse; meat products; vegetable oils and fats; dairy & \\
omt; vol; mil; & products; processed rice; sugar; food products; beverages & \\
pcr; sgr; ofd; b_t & and tobacco products & \\
OthPrimary; & coal, oil, gas, other mining; textiles, wearing apparel, & Other Manufacturing \\
texwap; woodpap & leather; lumber and paper products; petroleum, chemical, & & 10.89 \\
pchemineral; metals, & mineral; ferrous, metals, and metal products; motor vehicles & \\
autos; othmnfcs; & and parts; transport equipment, machinery, manufactures; & \\
Electronics; hhutilities & electronics equipment; electricity, gas, water utility & \\
Construction & construction & Construction \\
Trade & trade & Wholesale \& Retail & 8.47 \\
Transport & water, air, and other transport & Transport \\
Comm & communications & Other Sectors & 8.39 \\
FinanceInsur & finance and insurance services & Finance \& Insurance & Perfect \\
Busservices & business services & Professional Services \\
Otherservice & recreational and other service & Perfect \\
PublidAdm & public administration, defence, health, education & Public Administration & 12.15 \\
\hline
\end{tabular}

Source: Angioloni and Wu (2020). 